\title{
Minimally invasive retroperitoneal necrosectomy in management of acute necrotizing pancreatitis
}

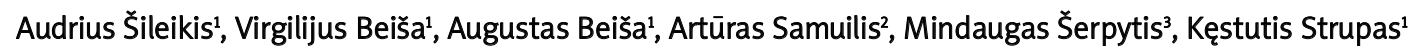 \\ ${ }^{1}$ Clinic of Gastroenterology, Nephrourology and Surgery, Faculty of Medicine, Vilnius University, Lithuania \\ ${ }^{2}$ Chair of Radiology, Nuclear Medicine and Medical Physics, Faculty of Medicine, Vilnius University, Lithuania \\ ${ }^{3}$ Clinic of Anesthesiology and Intensive Care, Faculty of Medicine, Vilnius University, Lithuania
}

Videosurgery Miniinv 2013; 8 (1): 29-35

DOI: $10.5114 /$ wiitm.2011.30943

\begin{abstract}
Introduction: One of the most important requirements in treatment of acute necrotizing pancreatitis is minimized invasion.

Aim: We are presenting experience in treatment of acute necrotizing pancreatitis by an original minimally invasive retroperitoneal necrosectomy technique, comparing our results to other studies, evaluating feasibility and safety, discussing advantages and disadvantages of this method.

Material and methods: We performed a retrospective analysis of 13 patients who had acute necrotizing pancreatitis with large fluid collections in retroperitoneal space and underwent retroperitoneal necrosectomy.

Results: There were eight males and three females aged between 24 and 60 years, average age was $42.8 \pm 9.2$ years. The most common cause of pancreatitis was alcohol, 10 patients (76.9\%). Average time between diagnosis and performance of operation was $25.7 \pm 11.3$ days. One patient underwent eight repeated interventions: two retroperitoneal necrosectomies; five laparotomies; ultrasound-guided drainage. One patient underwent four reinterventions: lumbotomy; revision; two lavages. Three patients had two reinterventions: one had laparotomy and tamponation; one had two repeated retroperitoneal necrosectomies; third had one repeated retroperitoneal necrosectomy and one had ultrasound-guided drainage. Three patients needed one additional retroperitoneal necrosectomy. Five patients did not required additional interventions. $61.5 \%$ of our patients did not require more than one reintervention. Postoperative stay varied from 9 to 94 days, average $50.8 \pm 32.6$ days.

Conclusions: Minimally invasive techniques should be considered as first-choice surgical option in treating patients with acute necrotizing pancreatitis. Pancreatic necrosis occupying less than $30 \%$ and with massive fluid collections in the left retroperitoneal space can be safely managed by minimally invasive retroperitoneal necrosectomy.
\end{abstract}

Key words: retroperitoneal necrosectomy, retroperitoneoscopy, necrotizing pancreatitis, minimally invasive pancreatic necrosectomy.

\section{Introduction}

Abdominal surgery is one of the disciplines where minimal invasive treatment methods spread rapidly. One of the most important requirements in treatment of acute necrotizing pancreatitis is minimized invasion. A lot of options exist today: percutaneous computed tomography (CT) or ultrasound-guided drainage, endoscopic necrosectomy, translumbar retroperitoneal endoscopic necrosectomy, and retroperitoneoscopic necrosectomy. All minimally invasive techniques show encouraging results. They have many

Address for correspondence:

Assist. Prof. Audrius Šileikis MD, Santariškių 2, 08406, Vilnius, Lithuania, phone: +37 052365250, fax: +37 052365101,

e-mail: audrius.sileikis@santa.It 
advantages in comparison with open surgery such as reduced inflammatory response to intervention, considerably reduced extent of bacteriemia, reduced risk of development of multi-organ failure, reduced rate of postoperative respiratory and wound complications, shorter stay in an intensive care unit (ICU), and faster convalescence [1]. The main problem is the variety of minimally invasive methods in treatment of acute necrotizing pancreatitis. That is why there is a lack of studies comparing minimally invasive versus open surgery and there is no consensus on the optimal surgical strategy.

\section{Aim}

The purpose of this article is to present our experience in treatment of acute necrotizing pancreatitis by an original minimally invasive retroperitoneal necrosectomy technique, to compare our results to other studies, and to evaluate the feasibility and safety of this method. Advantages and disadvantages of this method will be discussed.

\section{Material and methods}

We performed a retrospective analysis of $13 \mathrm{pa}$ tients who had acute necrotizing pancreatitis with large fluid collections in the retroperitoneal space and underwent retroperitoneal necrosectomy in 20072011. For all patients acute necrotizing pancreatitis was diagnosed by CT and infection of peri/pancreat- ic necrosis was proved by fine needle aspiration (FNA). Persistence of sepsis and peri/pancreatic infection were indications for intervention. The operation was performed for all patients regardless of localization and extent of inflammation. Results of the procedure were evaluated and compared to other studies.

\section{Technique of minimally invasive retroperitoneal necrosectomy}

We used an original technique, developed in our center, which was earlier reported by Šileikis et al. [1]. A patient was placed in the right lateral decubitus position and bent at the waist with the help of a roll. The first $10 \mathrm{~mm}$ trocar was inserted into the retroperitoneal fluid collection on the left medium axillary line near the ending of the $12^{\text {th }}$ rib under ultrasound guidance (Figure 1). Pneumoretroperitoneum should be created (up to $14 \mathrm{~mm} \mathrm{Hg}$ ). Then a $10 \mathrm{~mm}$ videoscope can be introduced to evaluate the cavity and content. Next two trocars were inserted under videoscope guidance on the left anterior axillary line and the left posterior axillary line. A suction irrigator and forceps were introduced through these trocars (Figure 2); then necrotic debris and pus were evacuated under visual guidance. Finally, the drains were placed through the sites of trocar puncture (Photos 1, 2), and on the next day, continuous lavage of the cleansed cavity was started. If purulent fluid collections extended to the minor pelvis, the fourth

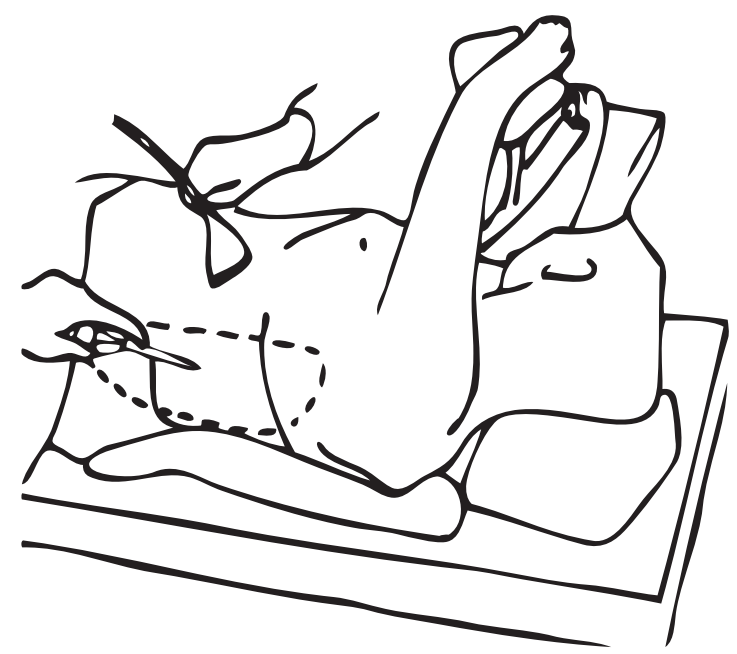

Figure 1. Trocar introduction into retroperitoneal fluid collection under ultrasound guidance [1] (with permission)

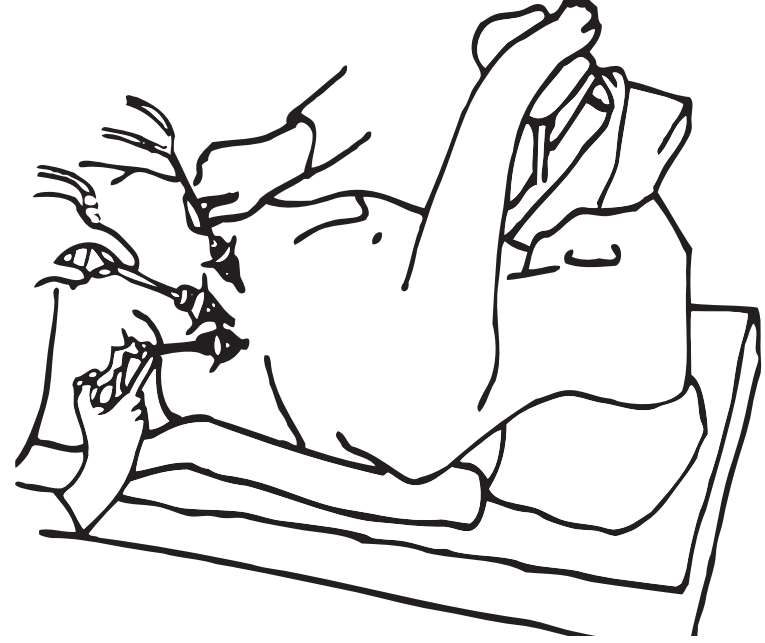

Figure 2. Placement of video scope, suction irrigator, and forceps during retroperitoneoscopic necrosectomy [1] (with permission) 

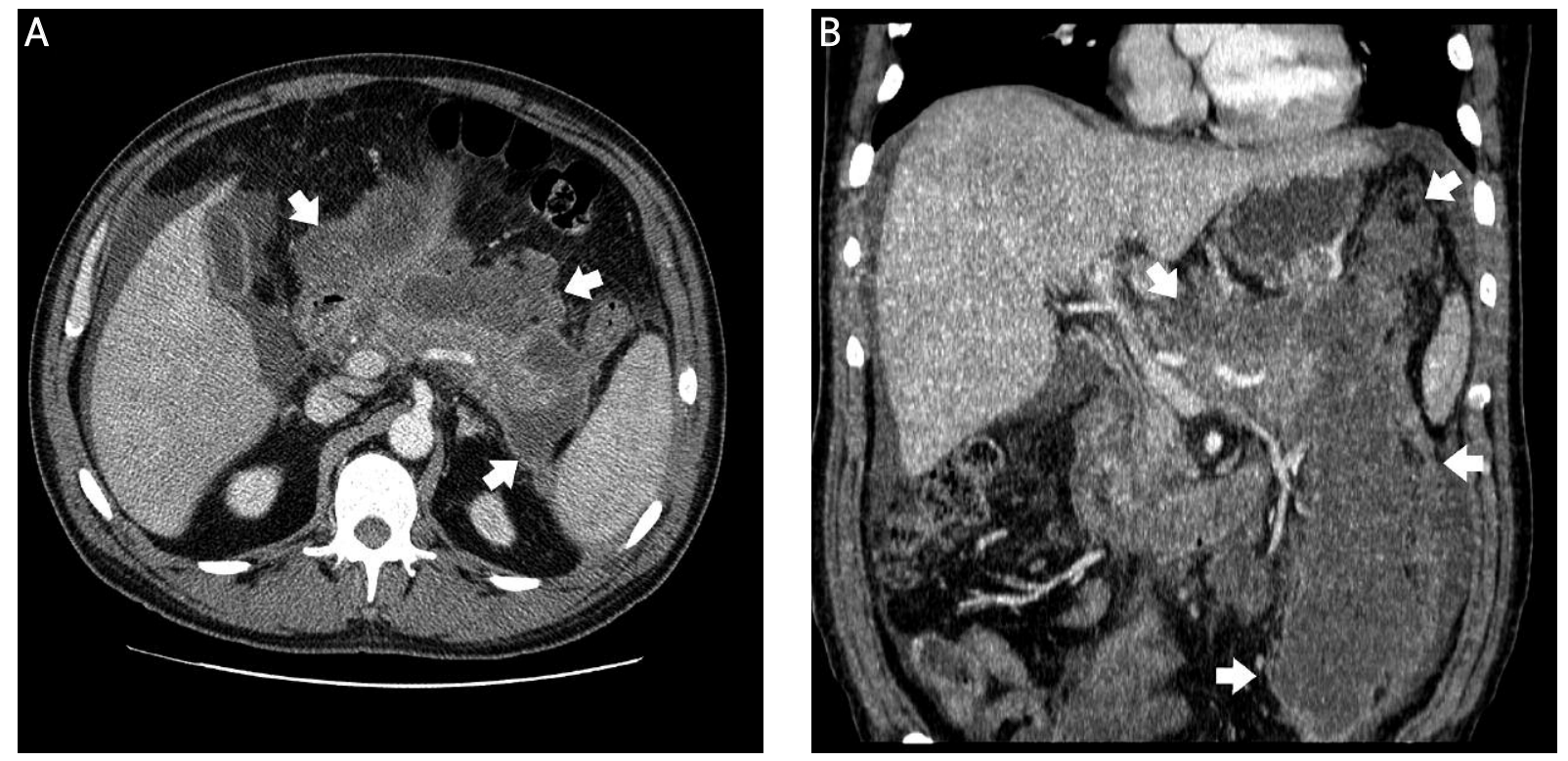

Photo 1. Patient with acute necrotizing pancreatitis. Axial contrast enhanced CT scan (A) and multiplanar reconstruction (B) show postnecrotic pancreatic/peripancreatic fluid collection (white arrows)
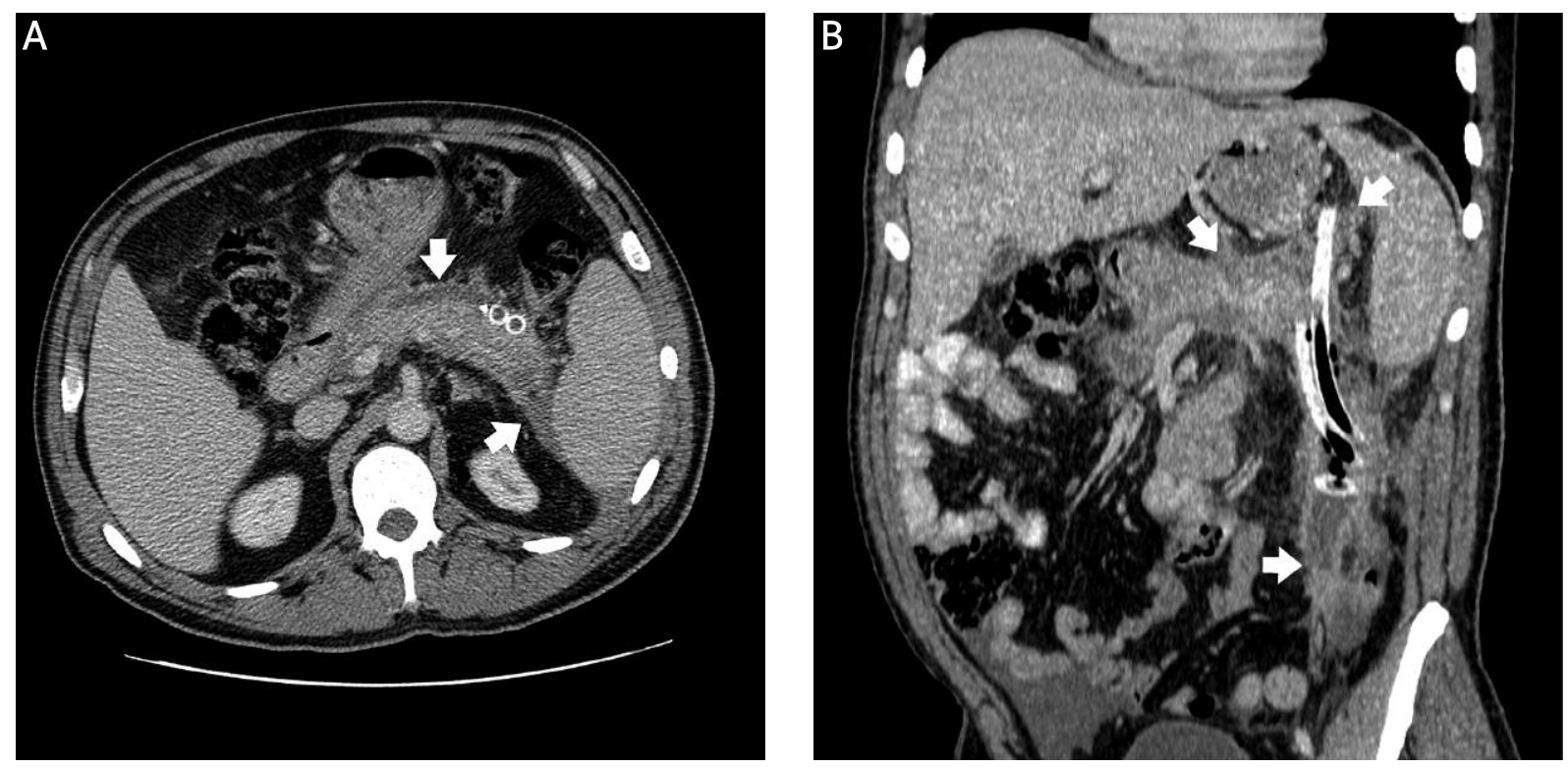

Photo 2. The same patient as in Photo 1. Axial contrast enhanced CT scan (A) and multiplanar reconstruction (B) show postnecrotic pancreatic/peripancreatic fluid collection after drainage (white arrows)

drain was placed there. During repeated retroperitoneoscopic necrosectomies, the trocars were inserted through the same apertures along with drain tracts.

\section{Results}

Table I presents details about our patients. The total number of patients who underwent retroperi- toneal necrosectomies was 13 . There were 8 males and 3 females aged between 24 and 60; average age was $42.8 \pm 9.2$ years. The most common cause of pancreatitis was alcohol, 10 patients (76.9\%); 2 patients (15.4\%) had iatrogenic pancreatitis (after extirpation of neuroendocrine tumor of pancreas and after endoscopic retrograde cholangiopancreatography); idio- 
Table I. Detailed data of results

\begin{tabular}{|c|c|c|c|c|c|c|c|c|}
\hline \multirow{2}{*}{$\begin{array}{l}\text { Patient } \\
\text { no. }\end{array}$} & \multirow{2}{*}{$\begin{array}{c}\text { Extent of } \\
\text { necrosis (\%)/ } \\
\text { localization }\end{array}$} & \multirow{2}{*}{$\begin{array}{c}\text { Fluid } \\
\text { collections in } \\
\text { retroperitoneal } \\
\text { space }\end{array}$} & \multicolumn{4}{|c|}{ Number of reinterventions $(n)$} & \multicolumn{2}{|c|}{ In-hospital stay [days] } \\
\hline & & & $\begin{array}{l}\text { Laparo- } \\
\text { tomies }\end{array}$ & $\begin{array}{l}\text { Retroperitoneal } \\
\text { necrosectomies }\end{array}$ & $\begin{array}{c}\text { Sonosco- } \\
\text { pically guided } \\
\text { drainages }\end{array}$ & Total & Preoperative & Postoperative \\
\hline 1 & $\begin{array}{l}30-50 \\
\text { Head-body }\end{array}$ & $\begin{array}{l}\text { In both sides } \\
\text { (in left extends } \\
\text { to lesser pelvis) }\end{array}$ & 5 & 2 & 1 & 8 & 27 & 94 \\
\hline 2 & 30 Head & $\begin{array}{c}\text { In right } \\
\text { (extends to } \\
\text { lesser pelvis) }\end{array}$ & 0 & $\begin{array}{l}\text { 2; Lumbotomy; } \\
\text { Revision }\end{array}$ & 0 & 4 & 26 & 97 \\
\hline 3 & $\begin{array}{c}>50 \\
\text { Body-tail }\end{array}$ & $\begin{array}{c}\text { In left } \\
\text { (extends to } \\
\text { lesser pelvis) }\end{array}$ & 0 & 2 & 0 & 2 & 15 & 44 \\
\hline 4 & $>50 \mathrm{Head}$ & $\begin{array}{l}\text { In right } \\
\text { (extends to pelvis) }\end{array}$ & 0 & 2 & 0 & 2 & 35 & 55 \\
\hline 5 & $\begin{array}{l}>50 \\
\text { Head-body- } \\
\quad \text { tail }\end{array}$ & $\begin{array}{c}\text { In left } \\
\text { (extends to pelvis) }\end{array}$ & $\begin{array}{c}\text { 1; Tampo- } \\
\text { nation }\end{array}$ & 0 & 0 & 2 & 19 & 79 \\
\hline 6 & $\begin{array}{c}>50 \\
\text { Body-tail }\end{array}$ & $\begin{array}{c}\text { In left } \\
\text { (extends to } \\
\text { lesser pelvis) }\end{array}$ & 0 & 1 & 0 & 1 & 22 & 89 \\
\hline 7 & $\begin{array}{l}<30 \\
\text { Head-body- } \\
\quad \text { tail }\end{array}$ & $\begin{array}{c}\text { In left } \\
\text { (extends to } \\
\text { lesser pelvis) }\end{array}$ & 0 & 1+ laparoscopy & 0 & 1 & 6 & 15 \\
\hline 8 & $\begin{array}{l}\text { 30-50 } \\
\text { Head-body- } \\
\text { tail }\end{array}$ & $\begin{array}{l}\text { In both sides } \\
\text { (extends to pelvis) }\end{array}$ & 0 & 1 & 0 & 1 & 26 & 58 \\
\hline 9 & $\begin{array}{l}>50 \\
\text { Body-tail }\end{array}$ & $\begin{array}{c}\text { In left } \\
\text { (extends to pelvis) }\end{array}$ & 0 & 0 & 0 & 0 & 15 & 27 \\
\hline 10 & $>50 \mathrm{Head}$ & $\begin{array}{c}\text { In left } \\
\text { (extends to pelvis) }\end{array}$ & 0 & 0 & 0 & 0 & 40 & 64 \\
\hline 11 & $\begin{array}{c}<30 \\
\text { Body-tail }\end{array}$ & $\begin{array}{c}\text { In left } \\
\text { (extends to pelvis) }\end{array}$ & 0 & 0 & 0 & 0 & 46 & 9 \\
\hline 12 & $\begin{array}{l}>50 \\
\text { Head-body- } \\
\quad \text { tail }\end{array}$ & $\begin{array}{c}\text { In left } \\
\text { (extends to } \\
\text { lesser pelvis) }\end{array}$ & 0 & 0 & 0 & 0 & 37 & 20 \\
\hline 13 & $\begin{array}{l}30-50 \\
\text { Head-body }\end{array}$ & $\begin{array}{c}\text { In left } \\
\text { (extends to } \\
\text { lesser pelvis) }\end{array}$ & 0 & 0 & 0 & 0 & 20 & 10 \\
\hline
\end{tabular}


pathic pancreatitis was diagnosed for one patient (7.7\%). Fluid collections were diagnosed for all patients. Two patients had fluid collections in both sides of the retroperitoneum, two in the right side only, and the others in the left side of the retroperitoneum. Average time between diagnosis of acute necrotizing pancreatitis and performance of the operation was $25.7 \pm 11.3$ days. There were no intraoperative complications and no deaths. One patient (who had $30-50 \%$ pancreatic necrosis in the head and body of the pancreas and fluid collections in both sides of the retroperitoneum) underwent eight repeated interventions: two retroperitoneal necrosectomies because of insufficient drainage; five laparotomies because of bleeding, suspected fistula and ileus; and ultrasound-guided drainage because of infected walled-off pancreatic necrosis. One patient (with 30\% pancreatic necrosis in the head of the pancreas and fluid collection in the right side of the retroperitoneum) underwent four reinterventions: lumbotomy because of insufficient drainage, revision, and two lavages for necrosectomy. Three patients had two reinterventions (with $>50 \%$ pancreatic necrosis): one of them had laparotomy and tamponation because of bleeding; one had two repeated retroperitoneal necrosectomies because of insufficient drainage; the third had one repeated retroperitoneal necrosectomy and one ultrasoundguided drainage. Three patients (with < 30, 30-50 and $>50 \%$ pancreatic necrosis) needed one additional retroperitoneal necrosectomy because of insufficiency of drainage. Five patients did not require additional interventions; they had $<30,30-50$, and 3 patients had $>50 \%$ pancreatic necrosis with fluid collections in the left retroperitoneal space. $61.5 \%$ of our patients did not require more than one reintervention. Postoperative stay varied from 9 to 94 days, with an average of $50.8 \pm 32.6$ days.

\section{Discussion}

Infection of pancreatic necrosis occurs in 10\% to $50 \%$ of patients with necrotizing pancreatitis and is one of the most feared surgical complications of acute pancreatitis [2]. Once peri/pancreatic necrosis becomes infected mortality increases steeply [3]. Infected pancreatic necrosis is usually followed by multiorgan failure, which is associated with a mortality approaching $100 \%$ in the absence of surgical treatment [2]. Intervention is indicated when infection of peri/pancreatic necrosis is proven by fine needle aspiration (FNA), peri/pancreatic gas collections in the necrotic cavity are depicted on CT scan, or when sepsis persists despite maximal support on the ICU $[3,4]$. The principles of surgical management of acute necrotizing pancreatitis are based on vigilant intensive care, establishing the presence of infection, and surgical debridement of the infected necrosis [5]. Surgical intervention is best done in the late phase, when necrotic tissue is demarcated from viable tissues potentially limiting the number of repeat unplanned debridements [5]. Furthermore, Navaneethan et al. report that retroperitoneal drainage using the delay-until-liquefaction strategy also appears to be successful [6]. Published mortality rates for open necrosectomy range from $6 \%$ [7] to 50\% [8]. Minimally invasive methods have many advantages in comparison with open surgery such as reduced inflammatory response to intervention, considerably reduced extent of bacteriemia, reduced risk of development of multi-organ failure, reduced rate of postoperative respiratory and wound complications, shorter stay in an ICU, and faster convalescence $[1,9,10]$.

Laparoscopic transabdominal access causes reduced operative injury, postoperative pain, and herniation rate in comparison with open surgery. Major disadvantages are limited operative field, complicated evacuation of viscous content, contamination of peritoneal cavity, and remaining likelihood of pancreatic and enterocutaneous fistulas [11].

In a series of 11 consecutive patients managed by translumbar retroperitoneal endoscopy, Castellanos et al. concluded that this procedure had no additional morbidity/mortality, facilitated lavage, minimized the need for subsequent surgery, and decreased the need for repeated CT [8]. A possible explanation, according to van Santvoort et al., is that the retroperitoneal approach induces less perioperative and postoperative stress than laparotomy because a small $(5 \mathrm{~cm})$ incision is used, the peritoneum is left intact, and the peritoneal cavity is not contaminated. He hypothesized that by minimizing the inflammatory "hit" of necrosectomy the retroperitoneal approach may reduce the risk of postoperative multiple organ dysfunction in the already critically ill patient [12]. However, it is debatable whether a $5 \mathrm{~cm}$ incision can be called minimally invasive.

Babu et al. and Shelat et al. state that the retroperitoneal approach may be selected in patients with 
left-sided, predominantly retroperitoneal necrosis with a predominantly semi-solid collection [13]. It needs to be repeated on several occasions in order to achieve clearance and is not able to deal with gallstones [8]. When necrosis is multifocal, discontinuous, located in the head or uncinate process of the pancreas, the possibility of retroperitoneal access decreases sharply $[1,5,8]$. However, Chang et al. note that multiple retroperitoneal spaces usually communicate [14]. We found that if modified, retroperitoneal necrosectomy can be used regardless of the localization of necrosis; the main requirement is fluid collections extending to the pelvis. When fluid collections are in the left side of the retroperitoneum, necrosis can be totally evacuated. Fluid collections in the right retroperitoneum often allow only partial evacuation of necrosis, but it delays open or laparoscopic necrosectomy. Also it is obvious that there is no single technique of retroperitoneal necrosectomy [13]. Raraty et al. have demonstrated that the percutaneous, retroperitoneal approach may be employed in up to $85 \%$ of patients requiring surgery for pancreatic necrosis [7]. But this method requires CT guidance. We used a considerably cheaper technique, introducing trocars under ultrasound guidance. Furthermore, if Seldinger's method is used then fluid collections in the retroperitoneal space are relatively small and we have found that in most cases this technique cannot be used.

The study by van Santvoort et al. showed that the minimally invasive step-up approach, as compared with primary open necrosectomy, reduced the rate of the composite end point of major complications or death, as well as long-term complications, health care resource utilization, and total costs, among patients who had necrotizing pancreatitis and confirmed or suspected secondary infection $[15,16]$.

For choosing percutaneous CT or ultrasound-guided drainage, translumbar retroperitoneal endoscopic necrosectomy, and retroperitoneoscopic necrosecto-

Table II. Comparison of our data with other series of retroperitoneoscopic necrosectomies

\begin{tabular}{|c|c|c|c|c|c|c|c|c|}
\hline Study & $N$ & $\begin{array}{c}\text { Delay to } \\
\text { necrosec-tomy, } \\
\text { days (median) }\end{array}$ & $\begin{array}{l}\text { Pre-op } \\
\text { infected } \\
\text { necrosis }\end{array}$ & Technique & $\begin{array}{c}\text { Procedures } \\
\text { per patient, } \\
n\end{array}$ & $\begin{array}{c}\text { Laparotomy } \\
\text { required, } \\
n\end{array}$ & $\begin{array}{c}\text { Postoperative } \\
\text { stay } \\
\text { [days] }\end{array}$ & Mortality \\
\hline $\begin{array}{l}\text { Gambiez et al. } \\
1998 \text { [17] }\end{array}$ & 20 & 18 & 13 & $\begin{array}{l}\text { Lumbotomy and } \\
\text { medianoscopy }\end{array}$ & $5 \pm 4$ (mean) & 2 & 62 & 2 \\
\hline $\begin{array}{l}\text { Chang et al. } \\
2006[14]\end{array}$ & 19 & 35 & 13 & $\begin{array}{l}\text { Left flank incision } \\
\text { and blunt dissection }\end{array}$ & N/A & 1 & 23.2 & 3 \\
\hline $\begin{array}{l}\text { Besselink et al. } \\
2006[3]\end{array}$ & 18 & 48 & 7 & $\begin{array}{c}\text { Left-sided lumbotomy } \\
\text { and VARD }\end{array}$ & $2(1-11)$ & $\mathrm{N} / \mathrm{A}$ & 100 & 2 \\
\hline $\begin{array}{l}\text { Mui et al. } \\
2005 \text { [18] }\end{array}$ & 9 & N/A & 9 & $\begin{array}{l}\text { Seldinger and } \\
\text { nephroscopy }\end{array}$ & $3(2-8)$ & 2 & 84 & 1 \\
\hline $\begin{array}{l}\text { Connor et al. } \\
2005 \text { [19] }\end{array}$ & 47 & 28 & 38 & N/A & $3(1-9)$ & 12 & 64 & 9 \\
\hline $\begin{array}{l}\text { Castellanos } \\
\text { et al. } \\
2005[11]\end{array}$ & 11 & 13 & 11 & $\begin{array}{l}\text { Left translumbar } \\
\text { and flexible } \\
\text { nephroscopy }\end{array}$ & $5(3-10)$ & 0 & 98 & 3 \\
\hline $\begin{array}{l}\text { Risse et al. } \\
2004 \text { [20] }\end{array}$ & 6 & 48 & 6 & $\begin{array}{l}\text { Seldinger and } \\
\text { nephroscopy }\end{array}$ & $2(1-4)$ & 0 & 26 & 0 \\
\hline $\begin{array}{l}\text { Carter et al. } \\
2004[21]\end{array}$ & 10 & 24 & 10 & $\begin{array}{c}\text { Nephrostomy, } \\
\text { nephroscopy and } \\
\text { sinus tract endoscopy }\end{array}$ & $3(1-6)$ & 1 & 42 & 2 \\
\hline Our data & 13 & 26 & 13 & $\begin{array}{l}\text { Retroperitoneal } \\
\text { necrosectomy }\end{array}$ & $3(1-9)$ & 2 & 51 & 0 \\
\hline
\end{tabular}


my, patients must be highly selected: collections must be semi-solid, unifocal, left-sided, with defined localization of necrosis. Success of our method is only determined by extent of fluid collection. It can be used for all patients with left, right or both sided fluid collections, when they reach the pelvis - then it is possible to place drains safely, without injury to the internal organs. The best results were shown by cases with massive fluid collections and less than $30 \%$ necrosis extent. Retroperitoneoscopic necrosectomy not only reduces operative injury, but also prevents contamination of the peritoneal cavity and abdominal wall defects [1]. If retroperitoneoscopic necrosectomies appear to be insufficient, patients can always be scheduled for conventional open surgery. Even then the likelihood of intraoperative complications of open surgery is reduced, because timing of the operation is considerably later. And these points are important for reducing mortality [1]. Table II presents management results compared with other studies.

\section{Conclusions}

We conclude that minimally invasive techniques should be considered a first-choice surgical option in treating patients with acute necrotic pancreatitis. Pancreatic necrosis occupying less than 30\% and with massive fluid collections in the left retroperitoneal space can be safely managed by minimally invasive retroperitoneal necrosectomy.

\section{References}

1. Šileikis A, Beiša V, Simutis G, et al. Three-port retroperitoneoscopic necrosectomy in management of acute necrotic pancreatitis. Medicina (Kaunas) 2010; 46: 176-9.

2. Bucher P, Pugin F, Morel P. Minimally invasive necrosectomy for infected necrotizing pancreatitis. Pancreas 2008; 36: 113-9.

3. Besselink MG, van Santvoort HC, Nieuwenhuijs VB, et al. Minimally invasive 'step-up approach' versus maximal necrosectomy in patients with acute necrotising pancreatitis (PANTER trial): design and rationale of a randomised controlled multicenter trial [ISRCTN13975868]. BMC Surgery 2006; 6: 6; doi:10.1186/14712482-6-6.

4. Haas B, Nathens AB. Surgical indications in acute pancreatitis. Curr Opin Crit Care 2010; 16: 153-8.

5. Lakshmanan R, lyer SG, Lee VT, et al. Minimally invasive retroperitoneal pancreatic necrosectomy in the management of infected pancreatitis. Surg Laparosc Endosc Percutan Tech 2010; 20: e11-5.

6. Navaneethan U, Vege SS, Chari ST, Baron TH. Minimally invasive techniques in pancreatic necrosis. Pancreas 2009; 38: 867-75.
7. Raraty MG, Halloran CM, Dodd S, et al. Minimal access retroperitoneal pancreatic necrosectomy: improvement in morbidity and mortality with a less invasive approach. Ann Surg 2010; 251: 787-93.

8. Shelat VG, Diddapur RK. Minimally invasive retroperitoneal pancreatic necrosectomy in necrotising pancreatitis. Singapore Med J 2007; 48: e220-3.

9. van Santvoort HC, Bakker OJ, Bollen TL, et al. A conservative and minimally invasive approach to necrotizing pancreatitis improves outcome. Gastroenterology 2011; 141: 1254-63.

10. Wilcox CM, Varadarajulu S, Morgan D, Christein J. Progress in the management of necrotizing pancreatitis. Expert Rev Gastroenterol Hepatol 2010; 4: 701-8.

11. Castellanos G, Piñero A, Serrano A, et al. Translumbar retroperitoneal endoscopy: an alternative in the follow-up and management of drained infected pancreatic necrosis. Arch Surg 2005; 140: 952-5.

12. van Santvoort HC, Besselink MG, Bollen TL, et al. Case-matched comparison of the retroperitoneal approach with laparotomy for necrotizing pancreatitis. World J Surg 2007; 31: 1635-42.

13. Babu BI, Siriwardena AK. Current status of minimally invasive necrosectomy for post-inflammatory pancreatic necrosis. HPB (Oxford) 2009; 11: 96-102.

14. Chang YC, Tsai HM, Lin XZ, et al. No debridement is necessary for symptomatic or infected acute necrotizing pancreatitis: delayed, mini-retroperitoneal drainage for acute necrotizing pancreatitis without debridement and irrigation. Dig Dis Sci 2006; 51: 1388-95.

15. van Santvoort HC, Besselink MG, Bakker OJ, et al. A step-up approach or open necrosectomy for necrotizing pancreatitis. N Engl J Med 2010; 362: 1491-502.

16. Makarewicz W, Kaska $Ł$, Stefaniak T, et al. Videoscopic procedures in gastrointestinal and endocrine surgery. Videosurgery Miniinv 2006; 2: 87-93.

17. Gambiez LP, Denimal FA, Porte HL, et al. Retroperitoneal approach and endoscopic management of peripancreatic necrosis collections. Arch Surg 1998; 133: 66-72.

18. Mui LM, Wong SK, Nq EK, et al. Combined sinus tract endoscopy and endoscopic retrograde cholangiopancreatography in management of pancreatic necrosis and abscess. Surg Endosc 2005; 19: 393-7.

19. Connor S, Alexakis N, Raraty MG, et al. Early and late complications after pancreatic necrosectomy. Surgery 2005; 137: 499-505.

20. Risse O, Auguste T, Delannoy P, et al. Percutaneous video-assisted necrosectomy for infected pancreatic necrosis. Gastroenterol Clin Biol 2004; 28: 868-71.

21. Carter CR, McKay CJ, Imrie CW. Percutaneous necrosectomy and sinus tract endoscopy in the management of infected pancreatic necrosis: an initial experience. Ann Surg 2000; 232: 175-80.

Received: 27.02.2012, revised: 29.06.2012, accepted: 21.07.2012. 